\title{
Growth, Feed Intake And Conversion Ratio of Improved Goats Fed Brachiaria Grass And Napier Grass Mixed With or Without Leucaena Leaf Meal
}

\section{Mupenzi Mutimura ( $\nabla$ mmutimura@yahoo.co.uk)}

Rwanda Agriculture and Animal Resources DevelopmentBoard https://orcid.org/0000-0001-7019-4152

Pierre Celestin Hitimana

Rwanda Agriculture and Animal Resources Development Board (RAB)

Felicien Shumbusho

Rwanda Agriculture and Animal Resources Development Board

Maximillian Manzi

Rwanda Agriculture and Animal Resources Development Board

\section{Research Article}

Keywords: Galla goat, crossbred goat, Mulato II, grass-legume mixture, body weight gain

Posted Date: August 4th, 2021

DOI: https://doi.org/10.21203/rs.3.rs-740086/v1

License: () (1) This work is licensed under a Creative Commons Attribution 4.0 International License. Read Full License 


\section{Abstract}

This study assessed the growth and feed intake performances of Galla goats and their crosses with local goats fed on Brachiaria grass cultivar Mulato II and Napier grass mixed with Leucaena leaf meal. Twenty-four Galla goats and 24 crossbred goats were selected and divided into four groups of three goats for each genotype and put in a partitioned house for goats' stall feeding. Goats from each group were identified using ear tags, randomised and then allotted one of the dietary treatments. Feed rations used as treatments were hay of Mulato II, silage of Napier grass, Mulato II, ML (67\% Mulato + 33\% Leucaena leaf meal) and NL (67\% Napier grass + 33\% Leucaena leaf meal). Individual goat weights were taken on a weekly basis. Feed samples of each diet were collected every week and analysed for nutritive values. The chemical composition of feed showed significant differences $(P<0.05)$ among diets. Absolute and relative nutrient intakes showed that Galla goat had a higher DM intake of NL compared to other diets and in crossbreds. Galla goats had a higher feed conversion ratio for DM from Napier and NL diets. Mulato II increased body weight up to $29 \%$ and $47 \%$ over Napier grass in crossbreds and pure Galla goats, respectively. The findings suggest that Mulato II could be a better feed resource for growing goats. Further studies should be conducted by increasing the levels of Leucaena leaf-meal in the diets and determine nitrogen retention and quality of meat under the same feeding regime.

\section{Introduction}

The goats' population in Rwanda is approximately 2.4 million and is the second most important meat production after beef (MINAGRI, 2020). They are an important genetic resource as they require low inputs and are easy to manage, making them suitable for the low-input production system. Additionally, their abilities to reduce their metabolism, efficient water use, minimisation nitrogen requirements, and efficient digestion of high-fibre forage are among the desired adaptive features of goats (Abioja et al., 2010; Monteiro et al., 2018). These characteristics enable them to continue providing milk and meat even when the animal has succumbed to drought (Rust and Rust, 2013; Berihulay et al., 2019). The productivity of livestock is strongly linked to both quality and quantity of feed resources which vary markedly throughout the year. This is because feed is one of the major inputs in livestock husbandry that can account for between $65-75 \%$ of the production cost (Kirkpinar and Açıkgöz, 2018). One of the limitations of livestock productivity in Rwanda is the limitation of suitable forage crops that can produce green fodder year-round (Mutimura et al., 2019). Producing supplementary feed on farm by establishing grass-legume forages would enable to overcome this problem. For example, mixed grass-legume forage system will produce higher dry matter yields with higher nutritive values than systems involving sole forage grass (Onifade and Akinola, 1986). Crude protein (CP) content of dry mature tropical grasses often falls below $8 \%$ and this cannot allow optimum microbial function in the rumen (Norton, 1994). The problem can be solved through supplementation with additional nitrogen, which is not always possible for small-scale production systems (Gitunu et al., 2003). Also, using improved forage species can improve the quality and quantity of the dry matter production, thus improve sustainable livestock productivity.

Brachiaria grass as a tropical forage grass has proved to be one of the pastures, which increase livestock productivity. In addition to its adaptability, tolerance and resistance, Brachiaria grass has a high forage quality and has shown to produce high dry matter production, making it capable of meeting the daily nutritional requirements of ruminant livestock, including goats (Machogu, 2013). The full potential ruminant livestock production can be exploited by expanding the forage resource base through introduction of climate smart forages that can increase the quantity and quality attributes hence, supplying the daily nutritional requirements of ruminant livestock. A number of studies on climate smart Brachiaria grass species have shown their nutritional quality, high biomass 
and palatability, tolerance to abiotic and biotic stresses and potential for high ruminant productivity (Mutimura et al., 2016; Mutimura and Ghimire, 2021). However, studies on suitable feed resources, especially grass hay or silage to increase goat performances are limited. Therefore, the objective of this study was to evaluate growth, feed intake and conversion ratio performances of Galla goats and their crosses with local goats fed on Brachiaria grasses cultivar Mulato II and Napier grass mixed with or without Leucaena leaf meal.

\section{Materials And Methods}

\section{Study area}

The feeding experiment using goats was carried out at one of the research stations of Rwanda Agriculture and Animal Resources Development Board (RAB) called Karama. The station is geographically located at an average altitude of $1,400 \mathrm{~m}$ above sea level and it lies between $30^{\circ} 25^{\prime} \mathrm{E}$ and $2^{\circ} 30^{\prime} \mathrm{S}$. The region is characterised as semiarid with a climate categorised as Aw type ${ }_{3-4}$ (Koppen classification). The climate is characterized by an average annual rainfall of $750 \mathrm{~mm}$, with an average temperature of $21.5^{\circ} \mathrm{C}$ per year (Munyemana, 2001).

\section{Management of animals}

Twenty-four (24) Galla goats (21.8 \pm 3.7 kg live weight) and 24 crossbred goats (Galla $\times$ Local goats) of $20.5 \pm 3.5 \mathrm{~kg}$ live weight were selected from the flock of RAB- Karama Station and divided into four groups of three goats for each genotype. Goats were familiar with browsing in the savannah composed of a vegetation composed of xerophilous thickets in thick formation. These thickets mix with other species, including Carissa sp., Haplocoelum spp., Olea spp., of the small lawns graminaceous, which grow between the thickets. The goats from each group were identified using ear tags, randomised and then allotted to one of the dietary treatments. Goats were reared in a housed which was built for the goats at Karama station and subdivided for goats' stall feeding. Routine disease control measures were undertaken to control ecto-parasites using recommended formulations of acaricides on the market. Anti-helminths mainly Albendazole was used against endo-parasites, especially in the wet season. Goat house was cleaned every morning before offering feeds.

\section{Feeding management}

Feed rations used as treatments were roughages including Napier grass (Pennisetum purpureum) and Brachiaria grass (Brachiaria hybrid cultivar Mulato II) which were fed as sole diets or mixed with Leucaena diversifolia leaf meal. The mixture in the diet was $67 \%$ grasses and $33 \%$ of Leucaena leaf meal. Leucaena leaf meal was harvested from Karama station forage plots after three of regrowth and dried under shed. Grasses were also grown at the station where they were harvested manually at $15 \mathrm{~cm}$ above ground after three months of regrowth and conserved as hay and silage for cv. Mulato II and Napier grass, respectively. The soils at the station are the sand and clay and the growing of the grasses was done without any fertiliser application. Feed offers were based on individual goat body weights while water and mineral blocks were given ad libitum. After a fortnight period of adaptation, diets offered were weighed and a sample was taken every morning and evening at 9:00 $\mathrm{h}$ and 15:00 h, respectively. Before feed offer, refusals were also weighted and samples taken. Every week, individual goat weights were measured using a spring balance (Original Hanson ${ }^{T M}$, Model $N^{0} 21$, Trade Mark $N^{0} 595766$ ). The feeding experiment lasted for a period of 12 weeks.

\section{Chemical composition and metabolisable energy of feeds}


Daily samples collected from feed offered and refused were analysed for the dry matter (DM), crude protein (CP), neutral detergent fibre (NDF), acid detergent fibre (ADF) and minerals including calcium (Ca) and Phosphorus (P). The DM was determined based on method ID 9420.5 (AOAC, 1990) and the CP was analysed using the method ID 984.13 (AOAC, 2006). The NDF and ADF were determined based on Van Soest et al. (1991) while the Ca and P were analysed using Atomic Absorption and Flame Emission Spectrophotometer (PerkinElmer, Inc., Precisely, A. Analyst 200). In addition, metabolisable energy (ME) in feed was determined based on in vitro gas production method and then calculated according to Menke et al. (1979; Eq. 1):

$\mathrm{ME}(\mathrm{MJ} / \mathrm{kg} \mathrm{DM})=2.2+0.136 \mathrm{~V}_{24}+0.057 \mathrm{CP}+0.0029 \mathrm{CP}^{2}$

Where $\mathrm{V}_{24}$ is a gas volume produced at 24 hours; CP is a crude protein analysed in the feed.

\section{Calculation of parameters}

Nutrient intakes by goats in diets including DM, CP, NDF, ADF, ME, Ca and P were estimated as the difference between feed offered and refused and they were corrected for their concentrations in the original feed samples as described by Balehegn et al. (2014). Furthermore, feed conversion ratio (FCR) was computed as the slope of the linear regressions of cumulative nutrient intakes of DM, CP, NDF and ADF on growth rates of goats. Also, the daily requirement on metabolisable energy for growing goats was computed according to AFRC (1993) as shown in the equations below (Eq. 2, 3, 4 and 5). In addition, the growth rates (g/day) were estimated from the slope of the linear regressions between weekly body weights of goats and the feeding period.

$M E_{m}(M J /$ day $)=(F+A) / k_{m}(2)$

Where $M E_{m}$ : Metabolisable energy for maintenance; $F$ : Fasting metabolism; $A$ : Activity allowance and $k_{m}$ : Efficiencies of utilization of ME for maintenance which equals to 1 for ruminant animals (AFRC, 1993).

$F(M J /$ day $)=0.31 W^{0.75}(3)$

Where $W$ is the body weight

Allowance activities for lowland goats is as follows:

$A(M J /$ day $)=0.019 W(4)$

$E V_{g}(M J / k g W G)=4.972+0.3274 W(5)$

Where $E V_{g}$ : Energy values for growth; $W G$ : Weight gain.

\section{Data analysis}

Chemical compositions and metabolisable energy of feeds up to 12 weeks were statistically analysed using GLM procedures of SAS (SAS, 20216 versions 9.4). Means were compared by using the PDIFF option of SAS. Data on nutrient intake, FCR and body weight gain were analysed using GLM procedures of SAS based on below model (Eq. 6):

$Y_{i j k}=\mu+G_{i}+F_{j}+P_{k}+G F_{i j}+e_{i j k}(6)$ 
Where $Y_{i j k}=$ Variable dependent; $\mu=$ Overall mean; $G_{i}=$ Animal effect; $F_{j}=$ Effect of diet;

$P_{k}=$ Period effect; $G F_{i j}=$ Interaction effect of genotype and feed; $\mathrm{e}_{\mathrm{ijk}}=$ Residual error.

Body weights of goats recorded at the beginning of the experiment were used as covariate during the analysis of effect of feeds on growth performance. In addition, means of individual and group of goats were separated using least significance difference (LSD) at the $5 \%$ level of significance.

\section{Results}

\section{Chemical composition of roughages}

Chemical composition of roughages used to feed goats showed differences where by Napier grass and Leucaena had higher dry matter (DM) content than Mulato II (Table 1). However, Mulato II had higher metabolisable energy (ME) than Napier grass and Leucaena. The latter tree legume had higher crude protein followed by Mulato II. Mineral contents showed that Leucaena had higher Ca and P compared to Napier grass and Mulato II. However, there was no significant difference $(P>0.05)$ between $\mathrm{P}$ of Leucaena and Mulato II (Table 1$)$.

Table 1

Chemical composition of roughages

\begin{tabular}{|llll|}
\hline Parameters & Mulato II & Napier grass & Leucaena \\
\hline DM (g/kg) & $449^{\mathrm{b}}$ & $747^{\mathrm{a}}$ & $664.5^{\mathrm{a}}$ \\
\hline $\mathrm{CP}(\mathrm{g} / \mathrm{kg} \mathrm{DM})$ & $135^{\mathrm{b}}$ & $73^{\mathrm{c}}$ & $231.2^{\mathrm{a}}$ \\
\hline NDF (g/kg DM) & $466.2^{\mathrm{a}}$ & $516.4^{\mathrm{a}}$ & $492.5^{\mathrm{a}}$ \\
\hline ADF (g/kg DM) & $427.5^{\mathrm{a}}$ & $442.9^{\mathrm{a}}$ & $315.5^{\mathrm{b}}$ \\
\hline ME (MJ/kg DM) & $8^{\mathrm{a}}$ & $7^{\mathrm{b}}$ & $7.2^{\mathrm{b}}$ \\
\hline Ca (g/kg DM) & $7.5^{\mathrm{b}}$ & $6.7^{\mathrm{b}}$ & $18.2^{\mathrm{a}}$ \\
\hline P (g/kg DM) & $2.4^{\mathrm{a}}$ & $1.4^{\mathrm{b}}$ & $1.9^{\mathrm{a}}$ \\
\hline
\end{tabular}

DM: Dry matter; CP: Crude protein; NDF: Neutral detergent fibre; Acid detergent fibre; Ca: Calcium; P: Phosphorus. Means in the row with the same superscript letter are not significantly different at $P<0.05$.

\section{Nutrient intakes and feed conversion ratio}

Absolute and relative nutrient intake by goats showed that pure Galla had a higher DM intake of Napier grass mixed with Leucaena diet (NL) compared to other diets and in crossbred goats (Table 2). In general, Galla goats had a higher DM intake from Napier grass based diets compared to Mulato II with Leucaena (ML) or sole Mulato II diets. However, in both groups of goats, CP intake from Mulato II based diets was higher than Napier grass based diets. Furthermore, both groups of goats had higher absolute and relative intakes of NDF and ADF from Napier grass based diets (Table 2). The ME intake (MEI) from the Mulato II based diet was higher than Napier grass based diets for the Galla goats, but no significant difference $(P>0.05)$ with Napier grass supplemented with Leucaena. Also, there was no significant difference $(P>0.05)$ between MEI from Mulato II based diets and Napier grass based 
diets. However, ME relative intake was higher in Galla group fed on NL, Napier alone and ML than in the rest of the other groups (Table 2).

For minerals, Napier grass and Mulato II diets had a higher Ca relative intake, whereas it was higher for absolute intake from Napier in Galla goat groups (Table 2). Nevertheless, NL diet had similar P intake with ML and Mulato II diets for the Galla groups. In general, Galla had higher absolute and relative intakes compared to crossbred GallaLocal (Table 2).

Table 2: Nutrients intake of roughages by goats 
Goat breed

\begin{tabular}{|c|c|c|c|c|c|c|c|c|}
\hline & Galla & & & & Galla $\times$ & & & \\
\hline Roughrages & $\begin{array}{l}\text { Mulato } \\
\text { II }\end{array}$ & ML & NG & $\mathrm{NL}$ & $\underset{\text { II }}{\text { Mulato }}$ & ML & NG & NL \\
\hline
\end{tabular}

\section{Absolute}

intake:

\begin{tabular}{lllllllll}
\hline DMI (kg/day) & $1.3^{\mathrm{bc}}$ & $1.5^{\mathrm{b}}$ & $2.1^{\mathrm{a}}$ & $2.7^{\mathrm{a}}$ & $1.1^{\mathrm{bc}}$ & $1.0^{\mathrm{c}}$ & $1.2^{\mathrm{bc}}$ & $1.3^{\mathrm{bc}}$ \\
\hline $\mathrm{CPI}(\mathrm{kg} /$ day $)$ & $0.4^{\mathrm{ab}}$ & $0.5^{\mathrm{a}}$ & $0.2^{\mathrm{cd}}$ & $0.5^{\mathrm{a}}$ & $0.3^{\mathrm{b}}$ & $0.3^{\mathrm{b}}$ & $0.1^{\mathrm{d}}$ & $0.2^{\mathrm{bc}}$ \\
\hline $\mathrm{NDFI}(\mathrm{kg} /$ day) & $1.4^{\mathrm{b}}$ & $1.4^{\mathrm{b}}$ & $1.4^{\mathrm{b}}$ & $1.9^{\mathrm{a}}$ & $1.1^{\mathrm{bc}}$ & $0.9^{\mathrm{c}}$ & $0.8^{\mathrm{c}}$ & $0.9^{\mathrm{c}}$ \\
\hline $\mathrm{ADFI}(\mathrm{kg} /$ day) & $1.3^{\mathrm{ab}}$ & $1.1^{\mathrm{b}}$ & $1.2^{\mathrm{ab}}$ & $1.5^{\mathrm{a}}$ & $1.0^{\mathrm{bc}}$ & $0.7^{\mathrm{c}}$ & $0.7^{\mathrm{c}}$ & $0.8^{\mathrm{c}}$ \\
\hline $\mathrm{MEl}(\mathrm{MJ} /$ day) & $26.2^{\mathrm{abc}}$ & $30.6^{\mathrm{a}}$ & $17.0^{\mathrm{cd}}$ & $22.6^{\mathrm{bc}}$ & $15.7^{\mathrm{d}}$ & $17.1^{\mathrm{cd}}$ & $14.0^{\mathrm{d}}$ & $16.0^{\mathrm{d}}$ \\
\hline $\begin{array}{l}\text { Ca intake } \\
\text { (g/day) }\end{array}$ & $23.2^{\mathrm{cd}}$ & $32.0^{\mathrm{b}}$ & $18.4^{\mathrm{d}}$ & $39.5^{\mathrm{a}}$ & $18.6^{\mathrm{d}}$ & $21.3^{\mathrm{d}}$ & $10.6^{\mathrm{e}}$ & $20.3^{\mathrm{cd}}$ \\
\hline $\begin{array}{l}\text { P intake } \\
\text { (g/day) }\end{array}$ & $7.4^{\mathrm{a}}$ & $6.5^{\mathrm{a}}$ & $3.9^{\mathrm{b}}$ & $5.9^{\mathrm{a}}$ & $6.0^{\mathrm{a}}$ & $4.3^{\mathrm{b}}$ & $2.2^{\mathrm{b}}$ & $3.0^{\mathrm{b}}$
\end{tabular}

\section{Relative intake:}

\begin{tabular}{|c|c|c|c|c|c|c|c|c|}
\hline $\begin{array}{l}\text { DMI (g/kg } \\
\left.W^{0.75}\right)\end{array}$ & $127.2^{\mathrm{C}}$ & $175.0^{\mathrm{b}}$ & $222.8^{a}$ & $260.7^{a}$ & $119.3^{c}$ & $107.8^{c}$ & $134.1^{\mathrm{bc}}$ & $145.5^{c}$ \\
\hline $\begin{array}{l}\mathrm{CPI}(\mathrm{g} / \mathrm{kg} \\
\left.\mathrm{W}^{0.75}\right)\end{array}$ & $38.3^{b}$ & $56.1^{a}$ & $21.7^{c}$ & $45.4^{\mathrm{ab}}$ & $35.9^{b c}$ & $34.6^{\mathrm{bc}}$ & $13.1^{d}$ & $25.3^{c}$ \\
\hline NDFI $\left(g / W^{0.75}\right.$ & $132.1^{b c}$ & $159.8^{a b}$ & $154 .^{a b}$ & $184.2^{\mathrm{a}}$ & $123.9^{b c}$ & $98.4^{\mathrm{c}}$ & $92.7^{c}$ & $102.8^{c}$ \\
\hline $\begin{array}{l}\text { ADFI (g/ } \\
\left.\mathrm{W}^{0.75}\right)\end{array}$ & $121.1^{b c}$ & $131.4^{\mathrm{ab}}$ & $132.1^{a b}$ & $145.2^{\mathrm{a}}$ & $113.6^{b c}$ & $80.9^{c}$ & $79.5^{c}$ & $81.0^{c}$ \\
\hline $\begin{array}{l}\text { MEl (MJ/ } \\
\left.W^{0.75}\right)\end{array}$ & $1.6^{b}$ & $2.6^{\mathrm{a}}$ & $2.8^{a}$ & $2.9^{a}$ & $1.5^{\mathrm{b}}$ & $1.7^{\mathrm{b}}$ & $1.8^{\mathrm{b}}$ & $1.8^{\mathrm{b}}$ \\
\hline $\begin{array}{l}\text { Ca intake } \\
\left(\mathrm{g} / \mathrm{kg} \mathrm{W} \mathrm{W}^{0.75}\right)\end{array}$ & $2.1^{b}$ & $3.7^{\mathrm{a}}$ & $2.0^{\mathrm{b}}$ & $3.8^{a}$ & $2.0^{\mathrm{b}}$ & $2.3^{b}$ & $1.2^{c}$ & $2.1^{\mathrm{b}}$ \\
\hline $\begin{array}{l}P \text { intake }(\mathrm{g} / \mathrm{kg} \\
\left.\mathrm{W}^{0.75}\right)\end{array}$ & $0.7^{a}$ & $0.8^{a}$ & $0.4^{b c}$ & $0.5^{\mathrm{ab}}$ & $0.6^{a}$ & $0.4^{\mathrm{b}}$ & $0.3^{c}$ & $0.3^{c}$ \\
\hline
\end{tabular}

ML: Mulato II (67\%) + Leucaena (33\%); NG: Napier grass; NL: Napier grass (67\%) + Leucaena (33\%); DMI: Dry matter intake; CPI: Crude protein intake; NDFI: Neutral detergent fibre intake; ADFI: Acid detergent fibre; $\mathrm{W}^{0.75}$ : Metabolic weight. Means in the row with the same superscript letter are not significantly different at $P<0.05$.

Feed conversion ratio (FCR) showed that Galla had higher FCR for DM from Napier and Napier-Leucaena based diets, but, in crossbred goats Mulato II and Napier grass based diets were not significantly different $(P>0.05)$. A similar trend was observed in FCR of CP where Mulato II and Napier grass both mixed with Leucaena in Galla groups were not significantly different ( $P>0.05$; Table 3 ). However, crossbred groups had higher FCR of CP in 
Mulato II based diets compared to Napier grass based diets (Table 3). A similar trend was observed in crossbred groups.

Table 3

Feed conversion ratio (FCR) by goats

\begin{tabular}{|c|c|c|c|c|c|c|c|c|}
\hline \multicolumn{9}{|l|}{ Goat breed } \\
\hline \multirow[b]{2}{*}{ Roughrages } & \multicolumn{4}{|l|}{ Galla } & \multicolumn{4}{|c|}{ Galla $\times$ Local } \\
\hline & Mulato II & $M L$ & NG & NL & Mulato II & $M L$ & NG & NL \\
\hline FCR of DM (kg/kg BW gain) & $1.5^{\mathrm{b}}$ & $1.6^{\mathrm{b}}$ & $3.4^{\mathrm{a}}$ & $3.7^{\mathrm{a}}$ & $1.6^{\mathrm{b}}$ & $0.9^{c}$ & $2.2^{b}$ & $1.6^{\mathrm{b}}$ \\
\hline FCR of CP (kg/kg BW gain) & $0.5^{\mathrm{bc}}$ & $0.5^{a b}$ & $0.3^{c}$ & $0.6^{\mathrm{a}}$ & $0.5^{\mathrm{b}}$ & $0.3^{\mathrm{c}}$ & $0.2^{c}$ & $0.3^{\mathrm{c}}$ \\
\hline FCR of NDF ( $\mathrm{kg} / \mathrm{kg}$ BW gain) & $1.6^{\mathrm{bc}}$ & $1.5^{\mathrm{bc}}$ & $2.3^{\mathrm{a}}$ & $2.6^{\mathrm{a}}$ & $1.7^{\mathrm{b}}$ & $0.8^{\mathrm{C}}$ & $1.5^{\mathrm{bc}}$ & $1.1^{\mathrm{C}}$ \\
\hline FCR of ADF (kg/kg BW gain) & $1.5^{\mathrm{b}}$ & $1.2^{\mathrm{bc}}$ & $2.0^{a b}$ & $2.1^{\mathrm{a}}$ & $1.6^{\mathrm{b}}$ & $0.7^{\mathrm{c}}$ & $1.3^{\mathrm{b}}$ & $0.9^{c}$ \\
\hline
\end{tabular}

NG: Napier grass; ML: Mulato II (67\%) + Leucaena (33\%); NL: Napier grass (67\%) + Leucaena (33\%); FCR: Feed conversion ratio; DM: Dry matter; CP: Crude protein; BW: Body weight; Means in the row with the same superscript letter are not significantly different at $\mathrm{P}<0.05$.

Table 4 shows the average daily weight gain (ADG) of two groups of goats. There was significant difference $(P<$ $0.05)$ between diets within each group of goats, but there was no significant difference $(P>0.05)$ between the two groups of goats. Higher ADG was observed in both groups of goats fed on Mulato II alone, ML and NL compared to Napier grass solely fed (Table 4).

Table 4: Average daily weight gain of goats

\begin{tabular}{lll} 
& Goat breed \\
\hline Feed & Galla (g/day) & Galla $\times$ Local (g/day) \\
\hline Mulato II & $10^{\mathrm{a}}$ & $7.6^{\mathrm{a}}$ \\
\hline $\mathrm{ML}$ & $10.4^{\mathrm{a}}$ & $12.7^{\mathrm{a}}$ \\
\hline Napier & $6.8^{\mathrm{b}}$ & $5.9^{\mathrm{b}}$ \\
$\mathrm{NL}$ & $8.1^{\mathrm{a}}$ & $9.8^{\mathrm{a}}$
\end{tabular}

ML: Mulato II (67\%) + Leucaena (33\%); NL: Napier grass (67\%) + Leucaena (33\%); Means in the row with the same superscript letter are not significantly different at $\mathrm{P}<0.05$.

\section{Metabolisable energy intake versus metabolisable energy required}

Observed metabolisable energy intake (MEI) and predicted ME for growing goats showed a very strong correlation. However, the observed MEI from the four diets was higher than the predicted ME for both groups of goats (Fig. 1a and $\mathrm{b}$ ). There was a strong positive correlation between observed MEI and predicted ME for Mulato II based diets, 
but a weak positive correlation for Napier grass based diets in crossbred goat groups (Fig. 1a). Furthermore, in groups of Galla goats, observed MEl and predicted ME from all diets had a strong negative correlation except for Mulato II based diet (Fig. 1b). Observed and predicted ME in Napier grass solely fed or supplemented with the Leucaena leaf meal was negatively high in both groups of goats.

\section{Discussion}

\section{Chemical composition of roughages}

Roughages used showed discrepancies in terms of nutritive values. Napier grass and Leucaena leaf meal had a higher dry matter content compared to Mulato II. The differences might be due to the level of maturity during the harvest where by the Napier grass and Leucaena were harvested after three months of regrowth. However, the DM for Leucaena is less than that reported by Harun et al. (2017). Furthermore, crude protein (CP) in all diets varied among roughages except Leucaena which had the highest CP as it is a legume. Mulato II had higher CP (135 g/kg DM) compared to Napier grass. The CP of Mulato II was higher at the harvest stage of three months more than the average range of Napier grass which is commonly from 7-11\% across the East African region (Paul et al., 2020). However, once harvested at an early stage it can reach to $15 \%$ of $\mathrm{CP}, 70 \%$ and $38 \%$ for NDF and ADF, respectively (Rambau et al., 2016). Notwithstanding the content of NDF and ADF in Napier grass, the NDF was lower than the NDF reported by the later authors for East Africa region but ADF was higher to that of the authors' observation. The two cell wall compositions were higher to what is recommended for dairy ruminants, which should range between $30 \%$ and $40 \%$ for ADF and NDF, respectively. This is because the two cell wall components are the major factors that affect energy and dry matter intakes (McDonald et al., 2011). However, our findings on ADF are similar to what Harun et al. (2017) observed while our results on NDF were less than those reported on Leucaena leaves and on Buffel grass hay (above 67\%) in Brazil (Ramos et al., 2019). The metabolisable energy (ME) from the Mulato II and $\mathrm{ML}$ diets was higher (8 MJ/ kg DM) than that of Napier grass mixed with Leucaena leaf meal. It was not a surprise because Mulato II is known for its high nutritional quality, including high content in ME (Mutimura et al., 2017; Mutimura and Ghimire, 2021). Its high nutritional quality was the impetus to increase milk yield and body weight gain in cattle up to $37 \%$ and 54.7\%, respectively (Mutimura et al. Unpublished; Mutimara et al., 2016).

Macro-minerals of $\mathrm{Ca}$ and $\mathrm{P}$ in the roughages showed that Leucaena leaf meal had higher Ca content compared to grasses. However, its P was similar to that of Mulato II. The discrepancies of macro-elements between shrubs and grasses was expected because shrub legumes have higher uptake of these minerals (Pant et al., 2004; Mclennon et al., 2020). The high $P$ in Mulato II in comparison to shrub legume has been reported in semi-arid and acidic soil prone areas of Rwanda (Mutimura and Everson, 2012). This means that the grass can be a good source of Ca and $P$ to meet the daily requirements of all categories of ruminant livestock.

\section{Nutrient intakes and feed conversion ratio}

Absolute and relative dry matter intake showed that Galla goats fed on sole Napier grass and Napier mixed with Leucaena leaf meal were higher compared to other diets and in crossbred groups. This might be due to the fact that goats were familiar to the diets because where they were used to browse they could find Napier grass and Leucaena in contrast to Mulato II, which was planted in a plot under protection unless cut and carried to the animals. However, there was a low correlation between the DM intake and the rest of nutritive values in the diets in the same Galla groups. This is because there was no significant difference between crude protein intake in NL diet, Mulato II and ML for Galla groups. This could be justified by the high content of CP in both Mulato II and ML 
compared to Napier grass where the increase of protein in a diet increases the intake (Gusha et al., 2015; Xia et al., 2018). Notwithstanding this, there was a higher CP intake in crossbreds for Mulato II and ML compared to Napier grass and NL in crossbred groups. This showed that pure breeds have a high capacity to consume high amount of DM compared to crossbreds.

Furthermore, high DM intake was correlated to high NDF and ADF intakes. A similar observation was reported by Castro-Montoya and Dickhoefer (2017) where the intake of higher NDF was associated with high DMI in small ruminant. Higher NDF and ADF intakes were observed in Galla goat groups fed on Napier grass and NL compared to the rest of diets and groups of goats. Furthermore, absolute and relative intakes of $\mathrm{Ca}$ and $\mathrm{P}$ showed correlation in the concentrations of these macro-elements in diets and their intakes. In both groups of goats, Galla goats had higher intakes compared to crossbred goats, especially for Ca in NL diets. This might be due to the high DM intake of NL diet in Galla goats.

Absolute ME was higher in ML and Mulato II, but for the relative intakes it was higher in Napier grass and NL for the Galla goat groups. However, for crossbred goat groups no significant difference was observed in the four diets. Though high absolute intakes for ME was observed in both Mulato II based diets, for a Galla goat to increase $1 \mathrm{~kg}$ body weight it required high ME in Napier grass based diets compared to Mulato II based diets. The reason could be the fact that Galla goat would have used much energy for other physiological processes, including movement, heat stress adaptation (McDonald et al., 2011). This was observed in growth performance where Galla goats fed Mulato II based diet had a significant daily body weight gain compared to those fed on Napier based diets.

Feed conversion ratio (FCR) for DM, CP, NDF and ADF from Napier and NL diets was higher in Galla goats, but, these parameters, except for CP were not significantly different in crossbred goats fed Mulato II and Napier grass based diets. The high FCR in Galla goats, Napier grass and NL showed that the breed would need to consume more of the diets for it to gain $1 \mathrm{~kg}$ of body weight, whereas it would require less in Mulato II and ML to gain the same weight. Generally, crossbred goats had better FCR because they would need less nutrient intakes to gain $1 \mathrm{~kg}$ of body weight. This could be justified by the fact that goats with indigenous bloods are adapted well in the local climatic conditions and well used to consume local forages. A similar observation was reported in a Tunisia arid land where indigenous goats could increase the intake of local forage and thus increase carcass weight (Ayeb et al., 2016).

Furthermore, observed metabolisable energy intake (MEI) and predicted ME for growing goats showed a very strong relationship. However, observed MEI was higher than that predicted. This means that the available ME in

feed was not fully used to induce growth of goats. A similar observation was reported by Mutimura et al. (2016) where metabolisable energy in diets composed of Mulato II or Napier grass supplemented with commercial concentrates was not translated into impressive body weight gains in crossbred heifers.

\section{Body weight gain}

When comparing the two roughages, Mulato II increased body weight up to $28.8 \%$ without supplement and $29.6 \%$ with a supplement of Leucaena leaf meal for crossbred (Galla $\times$ Local) while it increased body weight by $47 \%$ without supplement and $28.4 \%$ with a supplement of Leucaena leaf meal for pure Galla goats. The inclusion of Leucaena by $33 \%$ in diet of Napier grass and Mulato II induced growth performance less than $13 \mathrm{~g} /$ day. Other authors have reported growth performance of goats of $15 \mathrm{~g} /$ day and $32 \mathrm{~g} /$ day when fed Napier grass supplemented with Leucaena at 50\% and 75\%, respectively (Rusdy, 2018). In addition, ML diet slightly increased body weight gain by $4 \%$ for Galla goats compared to Mulato II sole fed. Interestingly, ML increased significantly the 
body weight gain up to $67 \%$ for crossbred goats compared to Mulato II sole fed to the crossbreds. For Napier grass supplemented with Leucaena within Galla goats, it increased body weight gain up to 19\%, whereas the same diet increased the body weight gain up to $66.1 \%$ in crossbred goats compared to Napier grass sole fed. Comparing Mulato II and Napier grass, it was found that Mulato II increased body weight gain up to $47 \%$ over Napier grass in Galla goats. The same trend showed that, Mulato II supplemented with Leunaena increased up to $28.4 \%$ compared with Napier grass supplemented with Leucaena in Galla goats. The comparison of the two grasses in crossbred goats, showed that ML increased up to $29.6 \%$ over NL while Mulato II sole feed II increased the body weight gain up to $28.8 \%$ compared to Napier grass alone.

When comparing the two groups of goats, Mulato II and ML increased body weight gain of $31.6 \%$ and $22.1 \%$ over crossbreds and Galla goats, respectively. Additionally, Napier grass and NL increased body weight gain of $15.3 \%$ and $21 \%$ over crossbreds and Galla goats, respectively. Generally, Mulato II or ML significantly increased body weight gain in both groups of goats compared to Napier grass or NL fed diet. The high body weight gains of goats fed to Mulato II or ML could be due to high crude protein and metabolisable energy content in the diets. Similar observations were reported that once the grass is mixed with legumes/shrubs increase quality of diets and palatability thus, increases goats' production (Alvarez et al., 2018; Osman et al., 2020). This is due to the quality of dry matter intake which characterises the increase of body weight gain. Gusha et al. (2015) reported similar trends where high dry mater intake increased body weight gain from $35 \mathrm{~g} /$ day to $55 \mathrm{~g} /$ day due to high energy and protein from Cactus diet. Our findings are less than those reported by the later authors. This might be due to the fact that goats used in the trials were familiar with browsing in the field full of shrubs and they were not used to feeding in confinement from cut and carried grasses. According to Speir (2018), goats will only prefer $20-30 \%$ of their diet to be grasses and at least $30-50 \%$ browse which could be as high as $60-90 \%$. Our trial diets used only $67 \%$ of the grasses and the remaining $33 \%$ being tree legumes.

\section{Conclusion}

The use of Mulato II and Napier grass supplemented with or without Leucaena leaf meal in feeding goats showed high intakes and feed conversion ratios. Also, the diets had a high ME energy that exceeded the daily requirement in goats. Though differences among the four diets in terms of body weight again were observed where Mulato II and ML had the highest ADG (10-10.4 g/day in Galla, and 7.6-12.7 g/day in crossbred goats), these average daily gains were not much impressed. This study concluded that economic gains can be obtained by livestock farmers in terms of profit due to increased daily and live body weight gains for goats fed with Mulato and Napier grass supplemented with legumes. From our results also, it is recommended that a similar study be conducted by increasing the levels of Leucaena leaf meal in feeding growing goats while determining the nitrogen retention and quality of meat under the same feeding regime.

\section{Declarations}

\section{Acknowledgements}

The first author is grateful to financial support from Sida (the Swedish International Development Cooperation Agency) for Climate-smart Brachiaria Grass Program and EU's Horizon 2020 program for InnovAfrica project (Grant Agreement number 727201).

\section{Funding}


This study was conducted with funding support from Sida (the Swedish International Development Cooperation Agency) for Climate-smart Brachiaria Grass Program and EU's Horizon 2020 program for InnovAfrica project (Grant Agreement number 727201).

\section{Conflict of interest}

The authors declare that there is no conflict of interest

Ethics approval

Not Applicable

Consent to participate (include appropriate statements)

Not Applicable

Consent for publication (include appropriate statements)

Not Applicable

\section{Data availability and material}

The data presented in this paper that support the findings of our research are available and can be obtained from the corresponding author upon their reasonable request.

Code availability (Software application or custom code)

Not Applicable

\section{Authors' contribution}

Mupenzi Mutimura, Pierre Celestin Hitimana, Felicien Shumbusho and Maximillian Manzi made the cconception and design of the study. Data were collected by Mupenzi Mutimura and Pierre Celestin Hitimana. The data were analysed and interpreted by Mupenzi Mutimura. Mupenzi Mutimura, Felicien Shumbusho and Maximillian Manzi wrote and revised critically the manuscript.

\section{References}

1. Abioja, M.O., Osinowo, O.A., Adebambo, O.A., Bello, N.J. and Abiona, J., 2010. Water restriction in goats during hot-dry season in the humid tropics: feed intake and weight gain. Archivos De Zootecnia, 59, 195-203.

2. AFRC (Agricultural and Food Research Council), 1993. Energy and protein requirements of ruminants. A manual prepared by AFRC advisory Technical committee on responses to nutrients. CAB International, Wallingford, UK, $159 \mathrm{p}$.

3. AOAC (Association of Official Analytical Chemists), 2006. Total nitrogen, Official Methods of analysis, 984.13, 18th edition. Association of official analytical chemists, Washington, DC.

4. AOAC, 1990. Association of official Analytical chemists. Official methods of analysis. 15th edition. A.O.A.C. Arlington Virginia, USA. 
5. Ayeb, N., Seddik, M., Atti, N., Atigui, M., Fguiri, I., Barmat, A. and Khorchani, T., 2016. Growth, feed intake and carcass characteristics of indigenous goats fed local resources in Tunisian arid land. Animal Production Science, 56, 1842-1848. http://dx.doi.org/10.1071/AN14879.

6. Balehegn, M., Eik, L.O. and Tesfay, Y., 2014. Replacing commercial concentrate by Ficusthonningii improved productivity of goats in Ethiopia. Tropical Animal Health and Production, 46, 889-894.

7. Berihulay, Haile; Abied, Adam; He, Xiaohong; Jiang, L. and Yuehui. M., 2019. "Adaptation Mechanisms of Small Ruminants to Environmental Heat Stress" Animals 9, no. 3: 75. https://doi.org/10.3390/ani9030075.

8. Birthe K. Paul, Jessica Koge, Brigitte L. Maass, An Notenbaert, Michael Peters, Groot, C.J. and Tittonell, P., 2020. Tropical forage technologies can deliver multiple benefits in Sub-Saharan Africa. A meta-analysis. Agronomy for Sustainable Development. 40: 22. https://doi.org/10.1007/s13593-020-00626-3.

9. Castro-Montoya, J. and Dickhoefer, U., 2017. Effects of tropical legume silages on intake, digestibility and performance in large and small ruminants: A review. Grass Forage Sci., 1-14. DOI: 10.1111/gfs.12324.

10. Gitunu, AM, Mnene, WN. And Muthiani, EN., 2003. Increasing the productivity of livestock and natural resources in Semi-Arid areas of Kenya: A case study from the Southern Kenya rangelands. Proceedings for end of programme conference, Agriculture/livestock research support programme, phase at KARI, Nairobi, Kenya.

11. Gusha, J., Halimani, T.E., Katsande, S. and Zvinorova, P.I., 2015. The effect of Opuntiaficusindica and forage legumes based diets on goat productivity in smallholder sector in Zimbabwe. Small Ruminant Research, 125: 21-25.

12. Harun, N. L. A., Alimon, A. R., Jahromi, M.F. and Samsudin, A.A., 2017. Effects of feeding goats with Leucaenaleucocephala and Manihotesculenta leaves supplemented diets on rumen fermentation profiles, urinary purine derivatives and rumen microbial population, Journal of Applied Animal Research, 45 (1): $409-$ 416. DOI: $10.1080 / 09712119.2016 .120549$.

13. João, F. R, Wandrick, H.S, Oliveira J.S, Filho, E.C.P, Santos, E.M, Leite, R.M, Rodrigues, IC. and Denizard O., 2020. Forage sources in diets for dairy goats. ActaScientiarum. Animal Sciences, 41, e46084, 2020.

14. Kirkpinar, F. and Açıkgöz, Z., 2018. Feeding. In: Animal Husbandry and Nutrition, pp: 97-113. http://dx.doi.org/10.5772/intechopen.78618.

15. Leeuw, P.N., Mohamed-Saleem, M.A. and Nyamu, A.M., 1992. Stylosanthes as forage and fallow crop. Proceedings of the regional workshop on the use of Stylosanthes in west Africa held in Kaduna Nigeria.

16. Machogu, C., 2013. A comparative study of the productivity of Brachiaria hybrid cv. mulato ii and native pasture species in semi-arid rangelands of Kenya. University of Nairobi, Kenya.

17. McDonald, P., Edwards, R.A., Greenhalgh, J.F.D., Morgan, C.A., Sinclair, L.A. and Wilkinson, R.G., 2011. Animal nutrition. Seventh Edition, Pearson Education Limited, Edinburgh Gate, Harlow, Essex CM20 2JE, England, 692 p.

18. Mclennon, E., Solomon, E.J.K.Q. and Davison, J., 2020. Grass-Legume Forage Systems Effect on Phosphorus Removal from a Grassland Historically Irrigated with Reclaimed Wastewater. Sustainability, 12, 2256; doi:10.3390/su12062256.

19. MINAGRI (Ministry of Agriculture and Animal Resources). Annual report 2020. ttps://www.minagri.gov.rw/fileadmin/user_upload/Minagri/Publications/Annual_Reports/Annual_report_201920_FY_.pdf. Accessed on 27 April 2021.

20. Monteiro, A., Costa, J. M. and Lima, M. J., 2018. Goat System Productions: Advantages and Disadvantages to the Animal, Environment and Farmer. Goat Science. doi:10.5772/intechopen.70002 
21. Munyemana, J. M.V., 2001. Evaluation of some agroforestry species for resistance to the termites on the grounds of Bugesera: Case of the Kayovu hill. Memoir, National University of Rwanda (NUR), Faculty of Agriculture, Butare, Rwanda.

22. Mutimura M., Ebong, C., Rao I.M. and Nsahlai, I.V., 2016. Change in growth performance of crossbred (Ankole $\times$ Jersey) dairy heifers fed on forage grass diets supplemented with commercial concentrates. Trop Anim Health Prod. 48 (4): 741-6. doi: 10.1007/s11250-016-1019-4.

23. Mutimura, M. and Everson, T.M., 2012. On-farm evaluation of improved Brachiaria grasses in low rainfall and aluminium toxicity prone areas of Rwanda. International Journal of Biodiversity and Conservation, 4:137-154.

24. Mutimura, M., Ebong, C., Rao, I. M. and Nsahlai, I.V., 2019. Seasonal variation of livestock feed resources in semi-arid and humid environments of Rwanda,East African Agricultural and Forestry Journal, 83 (2):137148,DOI: 10.1080/00128325.2019.1603578.

25. Mutimura, M., Ebong, C., Rao, I.M. and Nsahlai, I.V., 2017. Effect of cutting time on agronomic and nutritional characteristics of nine commercial cultivars of Brachiaria grass compared with Napier grass during establishment under semi-arid conditions in Rwanda. African Journal of Agricultural Research, 12(35): 26922703.

26. Mutimura, M. and Ghimire, S., 2021. Brachiaria grass for sustainable livestock production in Rwanda under climate change. IN: Leal Filho W., Luetz J., Ayal D. (eds.). 2021. Handbook of climate change management. Switzerland: Springer Nature: 1-17

27. Norton, B.W., 1994. Antinutritive and toxic factors in forage tree legumes. In: Tropical Tree Legumes in Tropical Agriculture. CAB International, Wallingford, UK, pp. 202-215.

28. Osman, A., Nawal, M.N. and Khalid, A.A., 2020. Effects of dietary supplementation with different concentration of molasses on growth performance, blood metabolites and rumen fermentation indices of Nubian goats. BMC Veterinary Research, 16:411. https://doi.org/10.1186/s12917-020-02636-5.

29. Pant, H.K, Adjei, M.B, Scholberg, J.M.S, Chambliss, C.G. and Rechcigl, J.E., 2004. Forage production and phosphorus phytoremediation in manure-impacted soils. Agron. J., 96: 1780-1786.

30. Rambau, Fushai, F. and Baloyi, J.J., 2016. Productivity, chemical composition and ruminal degradability of irrigated Napier grass leaves harvested at three stages of maturity. South African Journal of Animal Science, 46: 398-408.

31. Ríos, S. A., Méndez, P. and Fresno, M., 2018. Effect of feeding goats with leguminous shrubs (Chamaecytisusproliferus ssp. Palmensis and Bituminariabituminosa) on milk and cheese properties, Journal of Applied Animal Research, 46 (1): 1443-1451, DOI: 10.1080/09712119.2018.1531762.

32. Rusdy, M., 2018: A review of the effects of quality forage supplementation on growth performance of cattle and goats fed elephant grass basal diet. Livestock Research forRural Development. Volume 30, Article \#203. Retrieved March 29, 2021, from http://www.Irrd.org/Irrd30/12/muhru30203.html.

33. Rust, J.M. and Rust, T., 2013. Climate change and livestock production: A review with emphasis on Africa. South African Journal of Animal Science, 43(3), 256-267. Retrieved April 27, 2021, from

http://www.scielo.org.za/scielo.php?script=sci_arttext\&pid=S0375-15892013000300004\&lng=en\&tlng=en.

34. SAS, 2016. Statistics, Version 9.4. SAS Institute, Inc., Cary, NC, USA.

35. Speir, A., 2018.More than a tin can - Forage systems for goats.

https://site.extension.uga.edu/forageteam/2018/06/more-than-a-tin-can-forage-systems-for-goats. Retrieved March 29, 2021. 
36. Van Soest, P.J., Robertson, J.B. and Lewis, BA., 1991. Methods for dietary fibre, neutral detergent fibre and nonstarch carbohydrates in relation to animal nutrition. J. Dairy Sci. 74:3583-3597.

37. Xia, C., Rahman, M.A.U., Yang, H., Shao, T., Qiu, Q., Su, H. and Cao, B., 2018. Effect of increased dietary crude protein levels on production performance, nitrogen utilisation, blood metabolites and ruminal fermentation of Holstein bulls. Asian-Australas J AnimSci, 31, (10): 1643-1653.

\section{Figures}
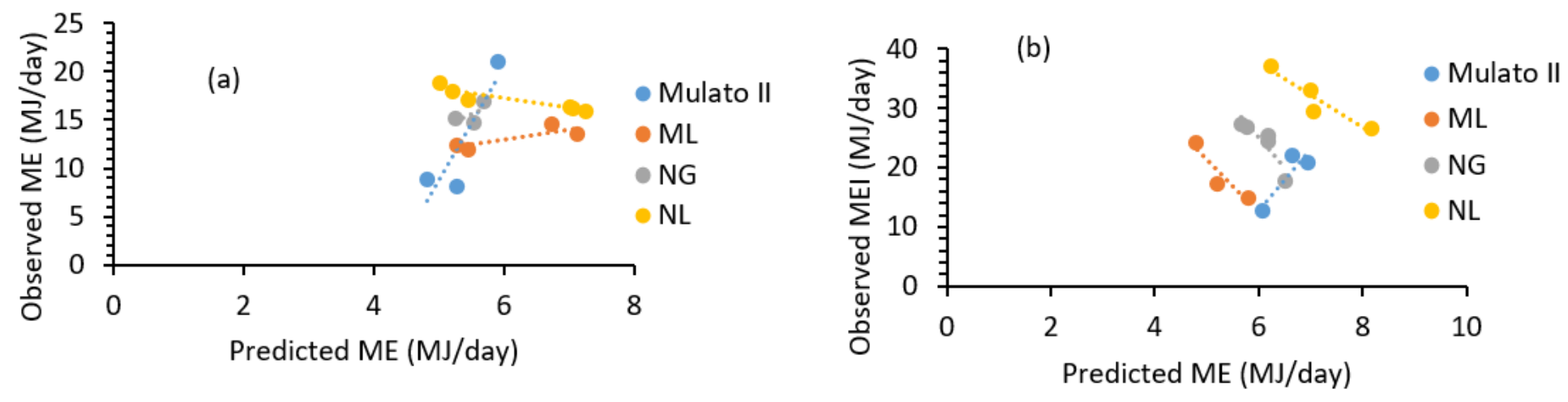

Figure 1

(a) Relationship between ME intake calculated and ME predicted for the four dietary groups of growing crossbred goats (Mulato II: $y=11.684 x-49.636, R^{2}=0.7958 ; M L: ~ y=1.009 x+6.9195, R^{2}=0.7034 ;$ NG: $y=3.0222 x-0.9702$, $\left.\mathrm{R}^{2}=0.3242 ; \mathrm{NL}: \mathrm{y}=-1.0078 \mathrm{x}+23.28, \mathrm{R}^{2}=0.8779\right)$; (b) Relationship between ME intake calculated and ME predicted for the four dietary groups of growing Galla goats (Mulato II: $y=10.334 x-49.201, R^{2}=0.8413 ; M L: y=$ $\left.-9.1729 x+67.308, R^{2}=0.8519 ; N G: y=-10.056 x+85.325, R^{2}=0.7821 ; N L: y=-5.4254 x+70.186, R^{2}=0.8854\right)$. 